\title{
Why do sika deer, Cervus nippon, debark trees in summer on Mt. Ohdaigahara, central Japan?
}

\author{
Masaki Ando ${ }^{1, *}$, Hiro-omi Yokota ${ }^{2}$ and Ei'ichi Shibata ${ }^{1}$ \\ ${ }^{1}$ Laboratory of Forest Protection, Graduate School of Bioagricultural Sciences, Nagoya University, Chikusa, Nagoya 464- \\ 8601, Japan \\ ${ }^{2}$ Laboratory of Grassland Science, Graduate School of Bioagricultural Sciences, Nagoya University, Chikusa, Nagoya 464- \\ 8601, Japan
}

\begin{abstract}
Bark stripping by sika deer, Cervus nippon, causes severe damage to forests. The seasonality of bark stripping by deer and tree selection were examined on Mt. Ohdaigahara in central Japan. The chemical content and physical properties of the bark were analyzed. About $60 \%$ of all tree species suffer various degrees of seasonal bark stripping. Bark stripping is most intensive during summer when the deer's main forage, Sasa nipponica, is abundant, suggesting that bark stripping is not due to food shortages. The bark physical properties seem to affect barking selection among three coniferous species, but not its seasonality. The nutritive value of bark is lower than that of S. nipponica, which has high crude protein and hemicellulose contents in summer but an inadequate mineral balance in summer, suggesting that sika deer eat the bark either to balance the digestible nutrients of summer forage and/or to attain a proper mineral balance in summer.
\end{abstract}

Key words: bark chemical content, bark physical property, bark selection, bark stripping, Cervus nippon.

Cervids have a profound impact on forest ecosystems (Anderson and Loucks 1979; Takatsuki and Gorai 1994; Akashi and Nakashizuka 1999; Fuller and Gill 2001; Virtanen et al. 2002) by browsing, bark stripping and fraying (Gill 1992). Above all, the impact of bark stripping causes the most severe problems, resulting in dieback of overstory trees and forest decline. Thus, deer debarking has serious effects on plant communities (Miquelle and Van Ballenberghe 1989; Akashi and Nakashizuka 1999). Bark stripping by cervids occurs worldwide: red deer, Cervus elaphus L., in Europe (McIntyre 1972; Welch et al. 1987; Motta 1996) moose, Alces alces L., in North America and Scandinavia (Miquelle and Van Ballenberghe 1989; Faber 1996; Randveer and Heikkila 1996), sambar, Cervus unicolor (Kerr), in India and New Zealand (Khan et al. 1994; Stafford 1997) and other cervids (Gill 1992; Parks et al. 1998). Bark stripping by sika deer, Cervus nippon Temminck, occurs in both primeval forests and managed plantations in Japan (Kaji et al. 1984; Oi and Itoya 1997; Yokoyama et al. 2001; Ueda et al. 2002; Ando et al.
2003; Nagaike and Hayashi 2003).

Sika deer in Japan have bark-stripping preferences (Sekine and Sato 1992; Kanzaki et al. 1998; Sakabe et al. 1998; Yokoyama et al. 2001; Ando et al. 2003). Miquelle and Van Ballenberghe (1989) also demonstrated that moose strip the bark of aspen and bebb willow, but not white spruce. Although seasonal observation of barkstripping preference for many tree species is required to clarify why deer debark trees, there are still no detailed observations.

The seasonal change in bark stripping in coniferous plantations showed that bark stripping is frequent in winter and spring (Welch et al. 1987; Faber 1996; Oi and Itoya 1997; Ueda et al. 2002). In Europe and North America, McIntyre (1972), Welch et al. (1987), Miquelle and Van Ballenberghe (1989), Gill (1992) and Motta (1996) presumed that deer eat bark due to food shortages in winter. Khan et al. (1994) also explained bark stripping by sambar resulting from food shortages caused by drought. In northern Japan, Kaji et al. (1984), Oi and Itoya (1997) and Ueda et al. (2002) mentioned that bark

*To whom correspondence should be addressed. E-mail: ando_m@agr.nagoya-u.ac.jp 
stripping by sika deer coincided with food shortages in winter and early spring.

However, in the primeval forest on Mt. Ohdaigahara, Yokoyama et al. (1996) used fecal analysis to show that deer ate bark of coniferous trees throughout the year and that bark stripping may occur most frequently in summer. In addition, Yokoyama and Shibata (1998) showed that the biomass and crude protein content of the dwarf bamboo, Sasa nipponica (Makino) Makino et Shibata the main forage of sika deer in this area - is highest in summer, suggesting that sika deer do not eat bark due to food shortages. The nutrients in bark (starch, water, sugar and other components) are not convincing evidence explaining why deer eat bark (Gill 1992).

Faber (1996) supposed the reason for bark stripping by moose in April and May was to ingest roughage for proper rumen function and/or to feed on a palatable food containing high starch and total carbohydrates. Oi and Itoya (1997) demonstrated that the bark of Cryptomeria japonica D. Don in plantations is easy to peel off in early spring when bark stripping occurs frequently, suggesting that the physical properties of bark affect the seasonal change in bark stripping and also affect the bark-stripping preference.
In this paper, we investigate (1) bark stripping seasonal occurrence and preference, (2) seasonal amount of stripped bark, (3) seasonal change in chemical content of bark compared to leaves of dwarf bamboo, the main forage of sika deer, and (4) seasonal change in physical properties of the bark of frequently stripped tree species. We clarify which tree species sika deer selectively debark, and when and why sika deer strip bark on Mt. Ohdaigahara.

\section{Materials and methods}

\section{Study site}

Mt. Ohdaigahara is located on the Kii Peninsula of central Japan (Fig. 1). Elevations vary from $1400 \mathrm{~m}$ in the west to $1600 \mathrm{~m}$ in the east with gentle slopes. Cool temperatures and heavy rainfall characterize the climate. The mean annual temperature and mean annual precipitation are $5.7^{\circ} \mathrm{C}$ and $\geq 4000 \mathrm{~mm}$, respectively. The vegetation of the primeval forest on Mt. Ohdaigahara can be divided into two major types. The eastern area is covered with coniferous forest, dominated by Picea jezoensis Carr. var. hondoensis Rehd. and Abies homolepis Sieb. et Zucc. The western area is mixed forest,

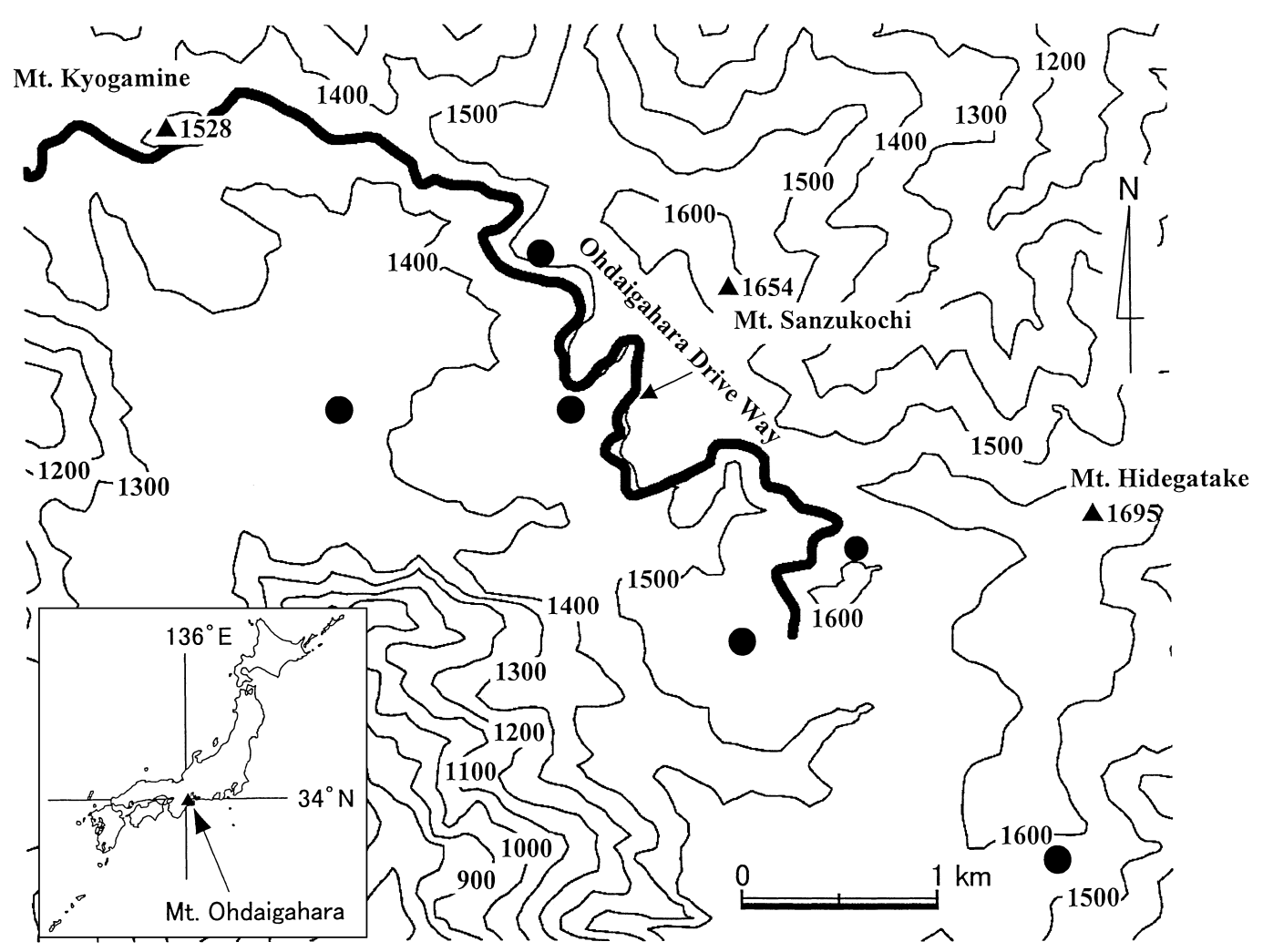

Fig. 1. Location of Mt. Ohdaigahara, central Japan. •: Transect. 
dominated by Fagus crenata Blume and A. homolepis. The dwarf bamboo, S. nipponica, covers most of the forest floor in the eastern area. The average density of sika deer on Mt. Ohdaigahara in spring 1997 was ca. 28 deer $/ \mathrm{km}^{2}$ (Maeji et al. 1999).

\section{Field measurements}

To determine the area of stripped bark, we established six belt transects $(8 \mathrm{~m} \times 50 \mathrm{~m})$ on Mt. Ohdaigahara in July 1999 (Fig. 1). In each transect, we measured the diameter at breast height ( $\mathrm{dbh})$ of all woody plants (height $\geq 1.6 \mathrm{~m}$ ). We measured the available bark area on the tree trunk (up to $1.6 \mathrm{~m}$ height) and butt swelling for deer by the method in Ando et al. (2003). When we found a stripping wound on a tree trunk, we marked the wound edges with tape to allow identification of new barking. On Mt. Ohdaigahara, there are two types of bark-stripping wounds caused by deer: feeding and fraying, which are classified easily by wound shape. In this study, only feeding wounds were checked. To clarify the seasonal change in bark stripping, we checked for new bark stripping on all trees every 2 months except in winter. We divided the seasons into spring (mid-May to mid-July), summer (mid-July to mid-September), fall (mid-September to mid-November), and winter (midNovember to mid-May).

To indicate deer preference for tree species, Ivlev's electivity index $(E)$ was calculated as follows (Ivlev 1965):

$$
E=\left(r_{i}-P_{i}\right) /\left(r_{i}+P_{i}\right) \quad(-1 \leq E \leq 1)
$$

where, $r_{i}$ is the ratio of damaged bark area of each species to total damaged bark area, and $P_{i}$ is the ratio of available bark area of each species to total available bark area. $E=0$ when deer bark randomly, $>0$ when deer bark preferably, and $<0$ when deer bark aversely.

\section{Chemical analysis}

To compare the chemical contents of bark stripped frequently by deer (Ando et al. 2003) and the leaves of dwarf bamboo, we collected the bark of $P$. jezoensis var. hondoensis, A. homolepis and Clethra barbinervis Sieb. et Zucc. and the leaves of two dwarf bamboos, S. nipponica and Sasamorpha borealis (Hack.) Nakai once every 2 months from September 1998 to July 2000. We selected five individuals of each tree species near the transects and collected bark (ca. $10 \mathrm{~cm} \times 10 \mathrm{~cm}$ ) including outer and inner bark and cambium from the trunk at breast height using a chisel. Bamboo leaves (ca. $100 \mathrm{~g}$, fresh weight) were clipped from plants near each transect. All samples were dried $\left(60^{\circ} \mathrm{C}, 48\right.$ hours $)$, milled, stored in a refrigerator, and then analyzed for crude protein, fibers (hemicellulose, cellulose and lignin) and minerals $(\mathrm{Ca}$, $\mathrm{Mg}, \mathrm{Na}$, and $\mathrm{K})$. We calculated the equivalent ratio of $\mathrm{K} /(\mathrm{Ca}+\mathrm{Mg})$ as an indicator of the mineral balance of the forage.

Crude protein is a typical indicator of the nutritional value of diet, and fiber is also an important indicator for evaluating feedstuffs of ruminant livestock. Four minerals are essential for bone formation $(\mathrm{Ca}$ and $\mathrm{Mg}$ ), enzyme activation ( $\mathrm{Ca}, \mathrm{Mg}$ and $\mathrm{K}$ ), lactation $(\mathrm{Ca})$, nerve and muscle function $(\mathrm{Ca}, \mathrm{Mg}$ and $\mathrm{K}$ ), and regulation of body fluid volume and osmolarity (Na and K) (Robbins 1993; Okumura and Tanaka 1995).

Nitrogen content was analyzed by the Kjeldahl technique and converted to crude protein content by multiplying the nitrogen content by 6.25 . Fiber was measured according to Van Soest and Wine (1967). Mineral content was determined by atomic absorption with atomic absorption spectrophotometer (AA-6200, Shimadzu, Kyoto, Japan).

\section{Determination of physical properties}

To clarify the physical properties of the bark of three coniferous species: $P$. jezoensis var. hondoensis, $A$. homolepis and Chamaecyparis obtusa (Sieb. et Zucc.) Endl., we examined the bark hardness and thickness once every month from April to November 2002. Three to five trees were sampled. The results were combined into the following periods: early spring (April and May), spring (June and July), summer (August and September), and fall (October and November). We could not examine any tests in winter (December to March) because of deep snow in this area.

We examined the bark hardness by two methods. A 2 $\mathrm{cm} \times 10 \mathrm{~cm}$ incision with uncut top edge was made in the bark of a live tree. The bottom cut end was attached to a spring balance and the maximum tension needed to tear the bark away from the tree (bark unrendability) was measured. In another method, a $5 \mathrm{~cm} \times 5 \mathrm{~cm}$ piece of bark including outer and inner bark was collected and its hardness (bark hardness) was measured with a soil sclerometer (Push Cone, Daiki Rika Kogyo, Tokyo, Japan). We also measured the thickness of outer, inner and total bark with a digital caliper. 


\section{Statistical analyses}

The data of the stripped bark area of total (all trees), coniferous, broadleaf and each tree species in three years were pooled in four seasons and the difference among the seasons was analyzed using a one-way ANOVA and Tukey's H.S.D. test $(P<0.05)$. Differences among the chemical contents of the leaves and barks were also analyzed using a two-way ANOVA $(P<0.05)$. When the interaction between seasons and species was detected in a two-way ANOVA, a one-way ANOVA with a Bonferroni correction and Tukey's H.S.D. test $(P<$ $0.006)$ in each chemical content was adopted for detecting the difference of species in each season. Differences among the physical properties of three coniferous species were analyzed using a two-way ANOVA and Scheffe's test $(P<0.05)$. When a two-way ANOVA showed the interaction between seasons and species, the differences among the species in each property were analyzed using a one-way ANOVA with a Bonferroni correction and Scheffe's test $(P<0.013)$ in each season. SPSS 7.5J for Windows (SPSS Inc., Chicago, U.S.A.) was used for all tests.

\section{Results}

\section{Occurrence of bark stripping}

The results of the field measurements between July 1999 and July 2002 for the six transects on Mt. Ohdaigahara are shown in Table 1. Twenty five species (4 coniferous, 21 broadleaf) were observed in the six transects. Fifteen species (4 coniferous, 11 broadleaf) were barked on the trunk. The percentage of barked coniferous trees $(69.0 \%)$ was higher than that of barked broadleaf trees $(19.0 \%)$.

Both the total available bark area and the stripped bark area of the coniferous trees were larger than those of

Table 1. Total stripped area and electivity indices $(E)$ in each species between July 1999 and July 2002 on six transects on Mt. Ohdaigahara. The real number observed at six transects $\left(2,400 \mathrm{~m}^{2}\right)$ was showed on the table.

\begin{tabular}{|c|c|c|c|c|c|c|c|}
\hline Species & $\begin{array}{c}\text { Number of } \\
\text { trees }\end{array}$ & $\begin{array}{l}\text { Number of } \\
\text { barked trees }\end{array}$ & $\begin{array}{c}\text { Basal area } \\
\qquad\left(\mathrm{m}^{2}\right)\end{array}$ & $\begin{array}{l}\text { Mean dbh } \\
(\mathrm{cm} \pm S D)\end{array}$ & $\begin{array}{l}\text { Available bark } \\
\text { area }\left(\mathrm{m}^{2}\right)\end{array}$ & $\begin{array}{l}\text { Stripped bark } \\
\text { area }\left(\mathrm{m}^{2}\right)\end{array}$ & $E$ \\
\hline \multicolumn{8}{|l|}{ Coniferous } \\
\hline Abies homolepis & 91 & $67(73.6 \%)$ & 3.22 & $20.1 \pm 6.9$ & 103.83 & 6.102 & 0.22 \\
\hline Picea jezoensis var. hondoensis & 19 & $18(94.7 \%)$ & 1.24 & $27.8 \pm 7.6$ & 37.27 & 1.503 & 0.03 \\
\hline Chamaecyparis obtusa & 29 & $12(41.4 \%)$ & 1.15 & $18.4 \pm 13.0$ & 33.50 & 0.808 & -0.22 \\
\hline Taxus cuspidata & 3 & - & - & - & - & - & - \\
\hline \multicolumn{8}{|l|}{ Broadleaf } \\
\hline Clethra barbinervis & 16 & $12(75.0 \%)$ & 0.07 & $6.7 \pm 3.9$ & 5.69 & 2.047 & 0.81 \\
\hline Ilex geniculata & 5 & $3(60.0 \%)$ & 0.01 & $4.2 \pm 0.8$ & 1.04 & 0.068 & 0.27 \\
\hline Sorbus commixta & 4 & $1(25.0 \%)$ & 0.06 & $13.3 \pm 5.5$ & 3.42 & 0.156 & 0.09 \\
\hline Pourthiaea villosa var. laevis & 35 & $6(17.1 \%)$ & 0.07 & $4.4 \pm 2.2$ & 7.72 & 0.241 & -0.10 \\
\hline Fraxinus lanuginosa f. serrata & 12 & $7(58.3 \%)$ & 0.18 & $12.8 \pm 5.8$ & 8.05 & 0.232 & -0.14 \\
\hline Viburnum wrightii & 4 & $1(25.0 \%)$ & 0.01 & $4.0 \pm 3.6$ & 0.75 & 0.014 & -0.35 \\
\hline Symplocos coreana & 31 & $3(9.7 \%)$ & 0.07 & $5.0 \pm 2.2$ & 7.89 & 0.064 & -0.65 \\
\hline Hamamelis japonica & 6 & $1(16.7 \%)$ & 0.07 & $12.1 \pm 3.1$ & 3.04 & 0.016 & -0.76 \\
\hline Acer shirasawanum & 38 & $2(5.3 \%)$ & 0.71 & $12.9 \pm 8.6$ & 27.50 & 0.018 & -0.97 \\
\hline Fagus crenata & 33 & $0(0.0 \%)$ & 1.88 & $20.6 \pm 17.6$ & 42.61 & 0 & -1 \\
\hline Quercus mongolica var. grosseserrata & 5 & $0(0.0 \%)$ & 0.19 & $17.2 \pm 14.8$ & 6.78 & 0 & -1 \\
\hline Acer sieboldianum & 1 & $0(0.0 \%)$ & - & - & - & - & - \\
\hline Berberis tschonoskii & 1 & $0(0.0 \%)$ & - & - & - & - & - \\
\hline Betula grossa & 3 & $2(66.7 \%)$ & - & - & - & - & - \\
\hline Eleutherococcus sciadophylloides & 3 & $0(0.0 \%)$ & - & - & - & - & - \\
\hline Kalopanax pictus & 2 & $0(0.0 \%)$ & - & - & - & - & - \\
\hline Phellodendron amurense & 1 & $1(100 \%)$ & - & - & - & - & - \\
\hline Stewartia monadelpha & 1 & $0(0.0 \%)$ & - & - & - & - & - \\
\hline Tilia japonica & 2 & $0(0.0 \%)$ & - & - & - & - & - \\
\hline Viburnum dilatatum & 1 & $0(0.0 \%)$ & - & - & - & - & - \\
\hline Viburnum furcatum & 1 & $0(0.0 \%)$ & - & - & - & - & - \\
\hline \multicolumn{8}{|l|}{ Subtotal } \\
\hline Coniferous & 142 & $98(69.0 \%)$ & 5.67 & $14.1 \pm 12.6$ & 176.15 & 8.423 & 0.12 \\
\hline Broadleaf & 205 & $39(19.0 \%)$ & 3.57 & $14.7 \pm 11.1$ & 124.73 & 2.996 & -0.22 \\
\hline Total & 347 & $137(39.5 \%)$ & 9.24 & $15.7 \pm 9.5$ & 300.89 & 11.419 & - \\
\hline
\end{tabular}

$-:$ not calculated $(n \leq 3)$ 
broadleaf trees. A. homolepis had the largest available bark area and the largest stripped bark area of all tree species (Table 1). P. jezoensis var. hondoensis and $C$. obtusa showed relatively large available bark area and relatively large stripped bark area (Table 1). Acer shirasawanum Koidz. had a relatively large available bark area and a small stripped bark area. Although $F$. crenata had a relatively large available bark area, no barking was found during the study period. C. barbinervis, Fraxinus lanuginosa f. serrata (Nakai) Hara and Pourthiaea villosa (Thunb.) Dence. var. laevis (Thunb.) Stapf. showed relatively large stripped bark areas. Ten broadleaf species including $F$. crenata did not suffer any bark stripping during this study period.

\section{Seasonal bark stripping}

The seasonal change in the stripped bark area from

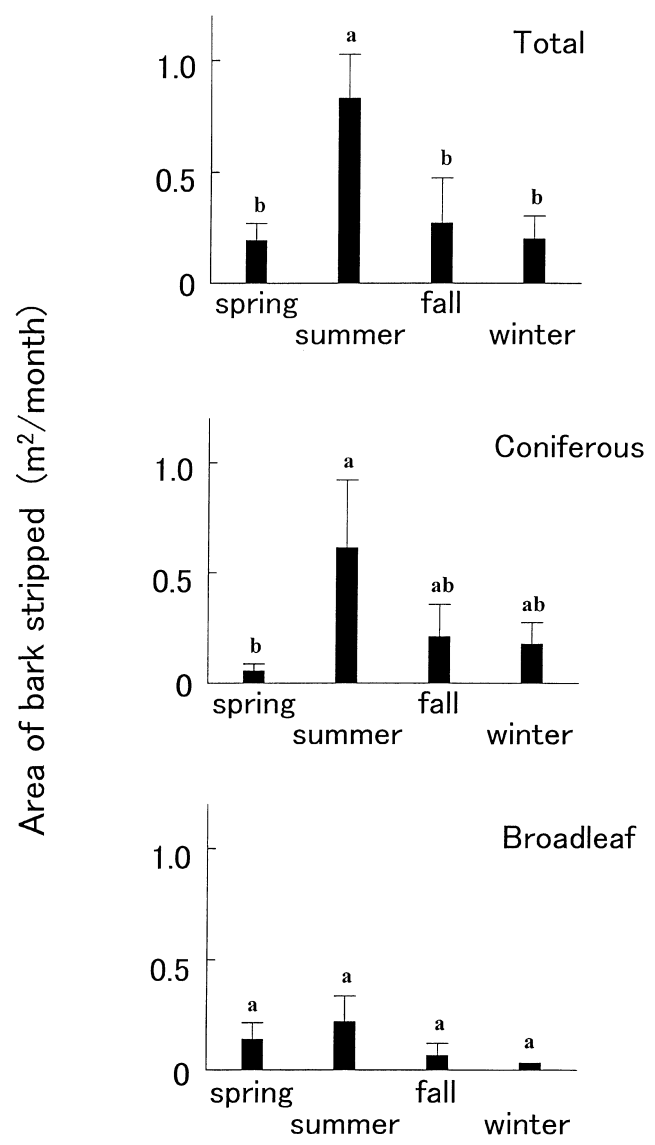

Fig. 2. The mean bark stripped area between July 1999 and July 2002, along six transects on Mt. Ohdaigahara, central Japan. Vertical bars show $S D$. Each season means from mid-May to mid-July (spring), mid-July to mid-September (summer), mid-September to mid-November (fall), and mid-November to mid-May (winter). Means followed by the different letters are significantly different (Tukey's H.S.D. test, $P<0.05)$.
July 1999 to July 2002 is shown in Fig. 2. The stripped bark area of total (all trees) in summer was significantly higher than that of other seasons (one-way ANOVA, $F=$ $11.679, P=0.003)$. The stripped bark area of coniferous trees in summer was also significantly higher than that of spring (one-way ANOVA, $F=5.557, P=0.023$ ). That of broadleaf trees showed a relatively indistinct peak in summer (one-way ANOVA, $F=3.818, P>0.05$ ).

The seasonal change in the stripped bark area of the six tree species that were largely stripped is shown in Fig. 3. The stripped bark area of P. jezoensis var. hondoensis had a clear peak in summer (one-way ANOVA, $F=24.758, P<0.001)$. Although the seasonal change in the stripped bark area of coniferous trees peaked in summer (Fig. 2), A. homolepis and C. obtusa did not show a clear peak in summer (one-way ANOVA, $F=$ 1.299, $P>0.05$ ) (Fig. 3). New bark-stripping wounds were observed on A. homolepis in every season. The stripped bark area of $C$. barbinervis was relatively large in spring and summer (one-way ANOVA, $F=2.644$, $P>0.05$ ). F. lanuginosa f. serrata (one-way ANOVA, $F=2.073, P>0.05$ ) and $P$. villosa var. laevis (one-way ANOVA, $F=1.082, P>0.05)$ did not show a clear seasonal change.

\section{Bark selection}

The number of barked tree species in spring was smaller than in other seasons (Table 2$)$. The electivity index for all coniferous trees $(E=0.12)$ was higher than that for broadleaf trees $(E=-0.22)$ (Table 1). The indices for coniferous species were relatively large, but those for broadleaf species varied with species. C. barbinervis had the largest electivity index $(E=0.81)$ followed by Ilex geniculata Maxim. (0.27) and A. homolepis (0.22) (Table 1). The electivity index for each tree species in each season is summarized in Table 2. The electivity indices for A. homolepis were relatively high in fall and winter. P. jezoensis var. hondoensis showed the highest electivity indices in summer. The electivity indices for C. barbinervis were very high in spring, summer and fall (Table 2).

\section{Chemical contents}

Figure 4 shows the seasonal change of the chemical contents of leaves and barks. There were significant differences among samples, seasons and their interactions in each chemical content (two-way ANOVA, Table 3). The crude protein and hemicellulose contents of the leaves of $S$. nipponica in each season were significantly 


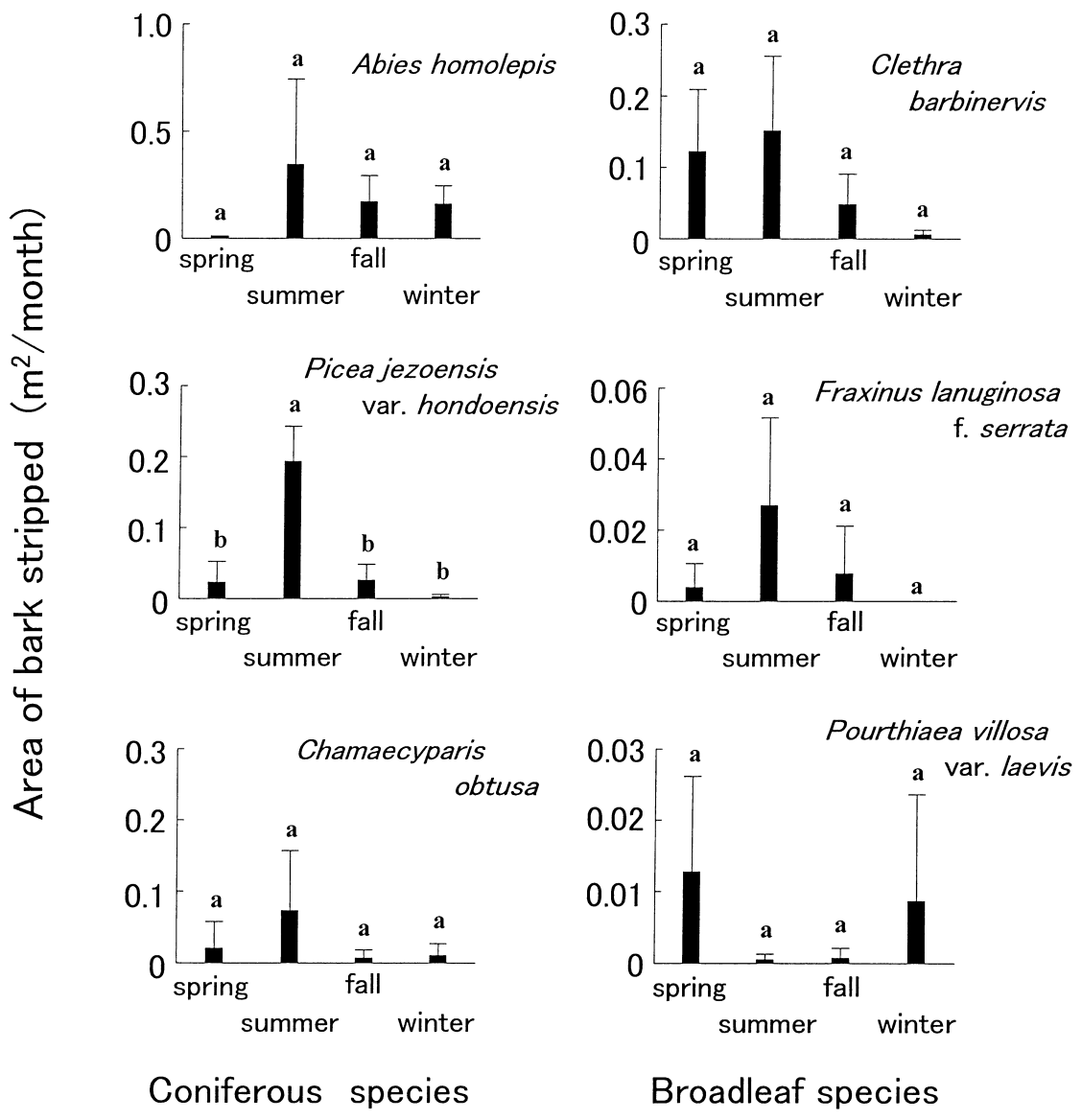

Fig. 3. The mean bark stripped area in six tree species stripped frequently in this study. Vertical bars show $S D$. Each season means from midMay to mid-July (spring), mid-July to mid-September (summer), mid-September to mid-November (fall), and mid-November to mid-May (winter). Means followed by the different letters are significantly different (Tukey's H.S.D. test, $P<0.05$ ).

Table 2. Electivity indices $(E)$ in each tree species $(n \geq 4)$ in four seasons on Mt. Ohdaigahara. The indices of three years were calculated with the data of stripped area which pooled in each season. Spring: mid-May to mid-July, Summer: mid-July to mid-September, Fall: mid-September to mid-November, Winter: mid-November to mid-May.

\begin{tabular}{lcccc}
\hline \multicolumn{1}{c}{ Species } & Spring & Summer & Fall & Winter \\
\hline Coniferous & & & & \\
$\quad$ Abies homolepis & -0.74 & 0.10 & 0.29 & 0.40 \\
Picea jezoensis var. hondoensis & -0.02 & 0.31 & -0.13 & -0.80 \\
Chamaecyparis obtusa & -0.01 & -0.12 & -0.61 & -0.35 \\
Coniferous total & -0.35 & 0.12 & 0.13 & 0.20 \\
Broadleaf & & & & \\
Clethra barbinervis & 0.94 & 0.81 & 0.81 & 0.24 \\
Fraxinus lanuginosa f. serrata & -0.15 & 0.10 & 0.03 & -1 \\
Ilex geniculata & -1 & 0.57 & -0.07 & -1 \\
Hamamelis japonica & -1 & -0.79 & -0.24 & -1 \\
Pourthiaea villosa var. laevis & 0.44 & -0.95 & -0.80 & 0.25 \\
Acer shirasawanum & -1 & -1 & -0.93 & -0.92 \\
Fagus crenata & -1 & -1 & -1 & -1 \\
Symplocos coreana & -1 & -1 & -0.48 & -0.32 \\
Quercus mongolica var. grosseserrata & -1 & -1 & -1 & -1 \\
Sorbus commixta & -1 & -0.90 & -0.21 & 0.55 \\
Viburnum wrightii & -1 & 0.05 & -1 & -1 \\
Broadleaf total & 0.27 & -0.23 & -0.27 & -0.52 \\
\hline
\end{tabular}



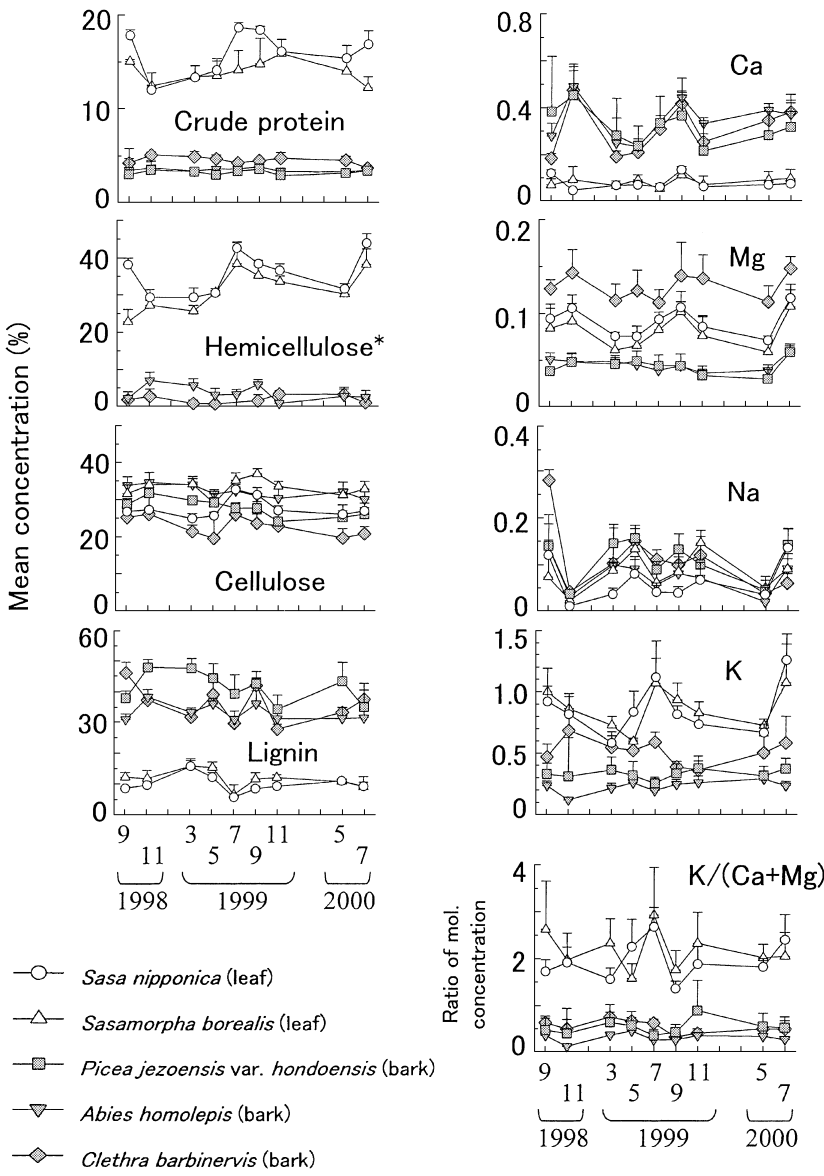

Fig. 4. Seasonal changes in each chemical content between September 1998 and July 2000. Error bars show SD. *: Hemicellulose was not detected in the bark of $P$. jezoensis var. hondoensis.

higher than those of bark (one-way ANOVA, Table 4). Although significant differences are detected in cellulose and Na by one-way ANOVA in each season (Table 4), the results of Tukey's H.S.D. test among samples in each season showed no clear trends between the bamboo leaves and tree bark. Lignin, which is an indigestible component, content of the tree bark was significantly higher than the contents of the bamboo leaves throughout the year (one-way ANOVA, Table 4). Except September 1998 and March 1999, Ca content of the tree bark was significantly higher than the contents of the leaves of $S$. nipponica throughout the year (one-way ANOVA, Table 4). The Mg content in the bark of C. barbinervis and the leaves of $S$. nipponica was significantly higher than the bark of $P$. jezoensis var. hondoensis and $A$. homolepis except May 1999. $\mathrm{K} /(\mathrm{Ca}+\mathrm{Mg})$ of the tree bark was significantly lower than that of the leaves of S. nipponica except March 1999 (one-way ANOVA, Table 4).

The crude protein, hemicellulose and $\mathrm{K}$ contents of
Table 3. The results of two-way ANOVA detecting the difference among bamboo leaves and tree barks in each chemical content.

\begin{tabular}{|c|c|c|c|}
\hline Chemical content & Source of variation & $F$ & $P$ \\
\hline \multirow[t]{3}{*}{ Crude protein } & Species & 1686.323 & $<0.001$ \\
\hline & Season & 8.241 & $<0.001$ \\
\hline & Species $\times$ Season & 6.585 & $<0.001$ \\
\hline \multirow[t]{3}{*}{ Hemicellulose } & Species & 3469.414 & $<0.001$ \\
\hline & Season & 26.667 & $<0.001$ \\
\hline & Species $\times$ Season & 17.940 & $<0.001$ \\
\hline \multirow[t]{3}{*}{ Cellulose } & Species & 161.852 & $<0.001$ \\
\hline & Season & 13.200 & $<0.001$ \\
\hline & Species $\times$ Season & 3.850 & $<0.001$ \\
\hline \multirow[t]{3}{*}{ Lignin } & Species & 1019.248 & $<0.001$ \\
\hline & Season & 19.588 & $<0.001$ \\
\hline & Species $\times$ Season & 4.776 & $<0.001$ \\
\hline \multirow[t]{3}{*}{$\mathrm{Ca}$} & Species & 154.958 & $<0.001$ \\
\hline & Season & 12.423 & $<0.001$ \\
\hline & Species $\times$ Season & 2.911 & $<0.001$ \\
\hline \multirow[t]{3}{*}{$\mathrm{Mg}$} & Species & 275.733 & $<0.001$ \\
\hline & Season & 15.080 & $<0.001$ \\
\hline & Species $\times$ Season & 1.616 & $<0.001$ \\
\hline \multirow[t]{3}{*}{$\mathrm{Na}$} & Species & 17.835 & $<0.001$ \\
\hline & Season & 26.889 & $<0.001$ \\
\hline & Species $\times$ Season & 4.697 & $<0.001$ \\
\hline \multirow[t]{3}{*}{ K } & Species & 207.212 & $<0.001$ \\
\hline & Season & 7.170 & $<0.001$ \\
\hline & Species $\times$ Season & 3.936 & $<0.001$ \\
\hline \multirow[t]{3}{*}{$\mathrm{K} /(\mathrm{Ca}+\mathrm{Mg})$} & Species & 333.475 & $<0.001$ \\
\hline & Season & 7.216 & $<0.001$ \\
\hline & Species $\times$ Season & 2.959 & $<0.001$ \\
\hline
\end{tabular}

S. nipponica had peaks in summer. The equivalent ratio of $\mathrm{K} /(\mathrm{Ca}+\mathrm{Mg})$ of $S$. nipponica overreached above 2.2 in May and July 1999 and July 2000, and peaked in July 1999.

\section{Bark physical properties}

Figure 5 shows the seasonal change of the physical properties of three coniferous species. There were significant differences among samples and sample-season interactions in bark unrendability (two-way ANOVA, species: $F=26.093, P<0.001$, season: $F=2.667, P=$ 0.054, interaction: $F=3.280, P=0.007)$, which of $C$. obtusa was significantly higher than that of $P$. jezoensis var. hondoensis and A. homolepis in spring and fall (one-way ANOVA, Table 5). The bark of A. homolepis was significantly harder both in inner bark (two-way ANOVA, species: $F=69.717, P<0.001$, season: $F=$ $0.496, P=0.612$, interaction: $F=1.224, P=0.312)$ and in outer bark (two-way ANOVA, species: $F=16.054$, $P<0.001$, season: $F=3.062, P=0.055$, interaction: $F=$ 
Table 4. The results of one-way ANOVA detecting the difference among each chemical content of bamboo leaves and tree barks in each month.

\begin{tabular}{crrrrrrrrrrr}
\hline Chemical content & & Sep., 98 & Nov., 98 & Mar., 99 & May, 99 & Jul., 99 & Sep., 99 & Nov., 99 & May, 00 & Jul., 00 \\
\hline Crude protein & $F$ & 153.721 & 103.462 & 211.876 & 167.031 & 278.584 & 163.486 & 262.580 & 215.782 & 264.555 \\
& $P$ & $<0.001$ & $<0.001$ & $<0.001$ & $<0.001$ & $<0.001$ & $<0.001$ & $<0.001$ & $<0.001$ & $<0.001$ \\
Hemicellulose & $F$ & 281.956 & 254.692 & 311.638 & 1075.034 & 272.359 & 620.148 & 1021.573 & 489.150 & 380.287 \\
& $P$ & $<0.001$ & $<0.001$ & $<0.001$ & $<0.001$ & $<0.001$ & $<0.001$ & $<0.001$ & $<0.001$ & $<0.001$ \\
Cellulose & $F$ & 11.764 & 10.887 & 59.257 & 11.368 & 34.265 & 36.089 & 28.458 & 21.877 & 24.724 \\
& $P$ & $<0.001$ & $<0.001$ & $<0.001$ & $<0.001$ & $<0.001$ & $<0.001$ & $<0.001$ & $<0.001$ & $<0.001$ \\
Lignin & $F$ & 195.956 & 223.299 & 151.437 & 114.499 & 88.770 & 161.848 & 117.377 & 95.323 & 57.995 \\
& $P$ & $<0.001$ & $<0.001$ & $<0.001$ & $<0.001$ & $<0.001$ & $<0.001$ & $<0.001$ & $<0.001$ & $<0.001$ \\
$\mathrm{Ca}$ & $F$ & 6.646 & 35.260 & 6.688 & 16.327 & 35.741 & 29.639 & 20.374 & 38.477 & 21.528 \\
& $P$ & 0.001 & $<0.001$ & $<0.001$ & $<0.001$ & $<0.001$ & $<0.001$ & $<0.001$ & $<0.001$ & $<0.001$ \\
$\mathrm{Mg}$ & $F$ & 35.984 & 30.700 & 32.571 & 27.544 & 43.253 & 22.264 & 33.665 & 43.193 & 39.150 \\
& $P$ & $<0.001$ & $<0.001$ & $<0.001$ & $<0.001$ & $<0.001$ & $<0.001$ & $<0.001$ & $<0.001$ & $<0.001$ \\
$\mathrm{Na}$ & $F$ & 8.944 & 36.970 & 4.117 & 7.531 & 6.694 & 6.228 & 4.849 & 1.969 & 6.101 \\
& $P$ & $<0.001$ & $<0.001$ & 0.014 & 0.001 & 0.001 & 0.002 & 0.007 & 0.138 & 0.002 \\
$\mathrm{~K}$ & $F$ & 42.179 & 12.645 & 28.137 & 27.141 & 31.034 & 73.322 & 50.150 & 26.643 & 21.163 \\
& $P$ & $<0.001$ & $<0.001$ & $<0.001$ & $<0.001$ & $<0.001$ & $<0.001$ & $<0.001$ & $<0.001$ & $<0.001$ \\
$\mathrm{~K} /(\mathrm{Ca}+\mathrm{Mg})$ & $F$ & 35.188 & 26.218 & 30.869 & 36.305 & 86.305 & 79.627 & 32.906 & 56.013 & 39.843 \\
& $P$ & $<0.001$ & $<0.001$ & $<0.001$ & $<0.001$ & $<0.001$ & $<0.001$ & $<0.001$ & $<0.001$ & $<0.001$ \\
\hline & & & & & & & & &
\end{tabular}

(kg)
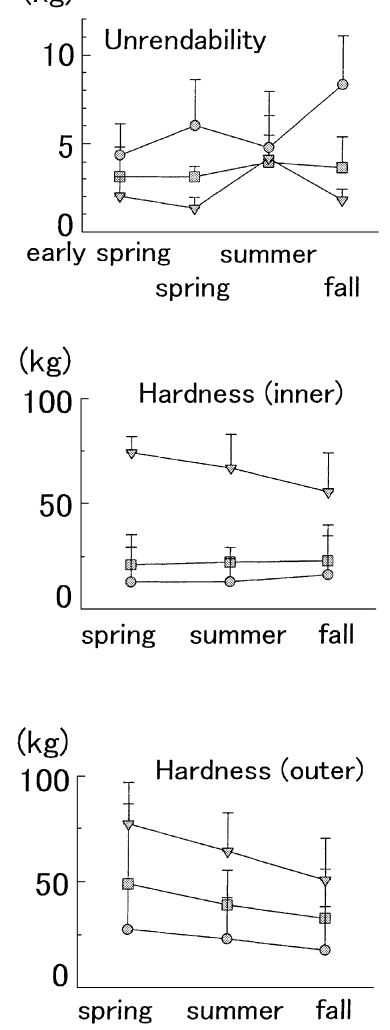

$(\mathrm{mm})$

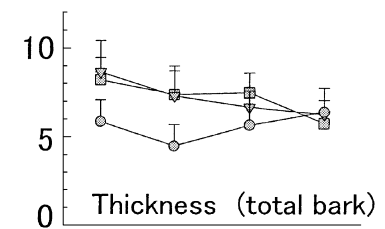

early spring summer spring fall

$(\mathrm{mm})$

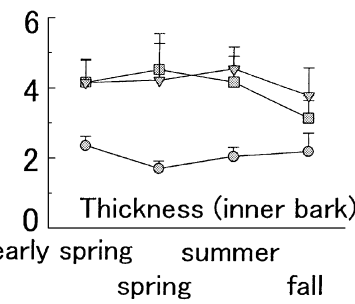

(mm)

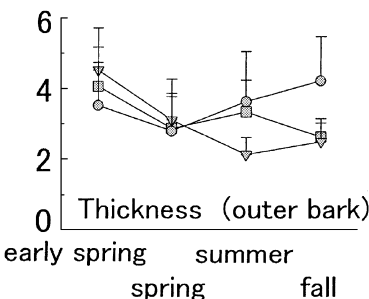

Table 5. The results of one-way ANOVA detecting the difference among each bark physical property of three coniferous species in each season.

\begin{tabular}{cccccc}
\hline Physical property & Early spring & Spring & Summer & Fall \\
\hline Unrendability & $F$ & 4.598 & 17.962 & 0.191 & 18.621 \\
& $P$ & 0.022 & $<0.001$ & 0.828 & $<0.001$ \\
Thickness & $F$ & 5.409 & 10.831 & 3.471 & 0.759 \\
(total bark) & $P$ & 0.021 & $<0.001$ & 0.058 & 0.485 \\
Thickness & $F$ & 17.515 & 26.124 & 32.538 & 9.900 \\
(inner bark) & $P$ & $<0.001$ & $<0.001$ & $<0.001$ & 0.002 \\
\hline
\end{tabular}

$0.239, P=0.915)$ throughout seasons. The thickness of the outer bark of the three species was not significantly different (two-way ANOVA, species: $F=1.397, P=$ 0.255, season: $F=4.136, P=0.010$, interaction: $F=$ 2.992, $P=0.012$ ). The thickness of the total bark did not show the clear trends in each season. Although significant differences are detected in thickness of the total bark by two-way ANOVA (species: $F=12.876, P<0.001$, season: $F=3.907, P=0.013$, interaction: $F=3.156, P=$ 0.009), one-way ANOVA and Scheffe's test among samples in each season showed no clear trends among

Fig. 5. Seasonal changes in bark physical properties of three coniferous species, Picea jezoensis var. hondoensis, Abies homolepis and Chamaecyparis obtusa. Error bars show $S D$. 
three species (Table 5). The significant difference among samples and sample-season interactions were detected in thickness of the inner bark (two-way ANOVA, samples: $F=69.400, P<0.001$, season: $F=$ 2.485, $P=0.069$, interaction: $F=2.364, P=0.040$ ), which of $C$. obtusa was significantly thinner than those of $P$. jezoensis var. hondoensis and A. homolepis, from early spring to summer (one-way ANOVA, Table 5). Hardness of the outer bark of the three species decreased as the year progressed; it was harder in spring and relatively softer in fall. Other properties did not show clear seasonal changes.

\section{Discussion}

\section{Occurrence of bark stripping}

Fifteen of the 25 tree species in the transects were barked by sika deer from July 1999 to July 2002. This was more than observed by Ando et al. (2003) and may be due to restricting the latter observation period for new barking to only 2 months in summer.

In this study, sika deer selected trees for bark stripping. In primeval forest, bark stripping by deer may change the forest composition (Miquelle and Van Ballenberghe 1989; Khan et al. 1994; Ando et al. 2003) because deer strip bark selectively and the tolerance of each species to bark stripping is different. Species that are debarked selectively and/or are not tolerant will decline and vice versa. Therefore, knowledge of barkstripping preference can help in forecasting and conserving the future forest community.

Heavy bark stripping on coniferous trees is well known on Mt. Ohdaigahara (Yokoyama et al. 2001), and coniferous bark was consumed in large quantities in this study. Ivlev's electivity indices show that the most preferred species is $C$. barbinervis followed by $I$. geniculata. The coniferous species were stripped relatively lightly in comparison to some broadleaf species. In Nikko, deer prefer A. homolepis and Quercus mongolica Fisch. var. grosseserrata Rehd. et Wils. to C. barbinervis (Kanzaki et al. 1998). Sakabe et al. (1998) also showed that in Hokkaido, sika deer prefer some broadleaf species, Ulmus laciniata (Trautv.) Mayr and Ulmus davidiana Planch. var. japonica (Rehder) Nakai, and the preference for coniferous species is relatively low. Although Norway spruce, lodgepole pine and ash are stripped frequently by red deer in Europe, bark-stripping preference differs in each area (Gill 1992).

On Mt. Ohdaigahara, our results that bark stripping peaked in summer follow the observation that the percentage of bark and twigs in the feces of sika deer tended to increase in summer (Yokoyama et al. 1996). One reason for intensive bark stripping in summer might be deer density because Ueckermann (1983), Kaji et al. (1984), Sekine and Sato (1992) and Gill (1992) found positive correlations between bark stripping and deer density. However, Maeji et al. (1999) showed that the deer densities estimated by the block count method in spring in 1997 and fall in 1996 on Mt. Ohdaigahara were 28.0 deer $/ \mathrm{km}^{2}$ and $30.9 \mathrm{deer} / \mathrm{km}^{2}$, respectively, and densities in summer in 1996 and 1997 were 17.5 deer $/ \mathrm{km}^{2}$ and $22.8 \mathrm{deer} / \mathrm{km}^{2}$, respectively. This might suggest that the deer density in summer on Mt. Ohdaigahara was not conspicuously higher than in spring and fall. Then, bark consumption by a deer might peak in summer on Mt. Ohdaigahara.

Bark stripping of sitka spruce, Picea sitchensis (Bong.) Carr. by red deer in western Scotland was more frequent in winter (Welch et al. 1987) and bark stripping of Pinus sylvestris L. by moose in south-central Sweden was more frequent in April and May (Faber 1996). The percentage of bark and twigs in the rumen contents or feces of sika deer in southernmost Honshu did not show any seasonal change (Jayasekara and Takatsuki 2000; Ikeda 2002). Deer in northern Japan strip bark intensively in winter, due to food shortages (Kaji et al. 1984; Ueda et al. 2002). However, this cannot explain why deer debark in summer on Mt. Ohdaigahara when the primary forage of sika deer, S. nipponica, has peak nutritional and quantitative values (Yokoyama and Shibata 1998).

\section{Why do deer eat bark in summer?}

This study showed that the bark of A. homolepis is relatively easy to be rent while being the hardest bark of the three coniferous species. It was also the bark most preferred by sika deer. The bark of C. obtusa was most difficult to be rent and most supple but sika deer showed no clear preference for it. Thus, among coniferous trees, sika deer on Mt. Ohdaigahara might prefer the bark which is harder and easier to be rent. Oi and Itoya (1997) reported that sika deer in Iwate Prefecture (northern Japan) strip the bark of $C$. japonica in spring when the bark is softest and easy to be rent. However, the physical properties of bark measured in this study showed no seasonal change and were not synchronized with bark stripping occurrence. These results suggest that the seasonal change in the occurrence of bark strip- 
ping on Mt. Ohdaigahara is not affected much by the bark physical properties but more by other factors, such as seasonal changes in the chemical content of the main forage and/or bark.

The seasonal changes in crude protein, hemicellulose and $\mathrm{K}$ in S. nipponica peaked in summer, corresponding with the change in the occurrence of bark stripping. Crude protein and hemicellulose are common indices for evaluating forage quality in ruminants, and lignin is known as indigestible component (Itabashi 1998). The chemical analyses showed that bark is less nutritional because it contains relatively lower crude protein and higher fiber than the main forage (Faber 1996; Yokoyama and Shibata 1998; Ando et al. 2003). Faber (1996) suggests that moose eat pine bark as roughage for proper rumen function. It is known that feeding high quality forage, like grain, to ruminants causes excess drop in $\mathrm{pH}$ in rumen fluid and prevents proper rumen function. A sudden switch in feed from roughage to concentrate sometimes causes lactic acidosis (Hoshino 1985). Previous studies (Yokoyama and Shibata 1998) and this study show that the nutritional value (crude protein and hemicellulose) of $S$. nipponica surges in summer. We supposed that the bark intake in summer prevents bloat or lactic acidosis from upsetting rumen function.

It is known that excessive $\mathrm{K}$ intake causes relative deficiency of another minerals (Robbins 1993). Kemp and t'Hart (1957) reported that a high value of $\mathrm{K} /(\mathrm{Ca}+$ $\mathrm{Mg}$ ) exceeding 2.2 tends to cause grass tetany. The $\mathrm{K} /$ $(\mathrm{Ca}+\mathrm{Mg})$ value of $S$. nipponica samples exceeded 2.2 in May and July 1999 and July 2000, and peaked July 1999 (Fig. 4), because of the increasing of $\mathrm{K}$ in summer. Conversely, the values for the bark of three tree species were always below 2.2. These results suggest that the mineral balance of $S$. nipponica is inadequate in July. We conceived that sika deer on Mt. Ohdaigahara feed on bark containing relatively large amounts of $\mathrm{Ca}$ to offset the poor mineral balance of $S$. nipponica. In addition, summer is the season for antler growth in male deer and for lactating in female deer, both of which require high $\mathrm{Ca}$ intake. To clarify the impact of $\mathrm{Ca}$ and $\mathrm{Mg}$ in bark, we need to assay the percentage of $\mathrm{Ca}$ and $\mathrm{Mg}$ derived from bark in the total $\mathrm{Ca}$ and $\mathrm{Mg}$ intake.

Acknowledgments: We thank H. Fukumoto, H. Ishikawa, M. Ito, K. Kato, T. Kurosaki, N. Kanda, M. Matsumura, H. Nagase, S. Nakamura, K. Ohi, M. Saito, A. Sasamoto, G. Takayama, K. Yatagai and S. Yokoyama for their kind help with the fieldwork. Thanks are also due to K.
Goto, Y. Hirano and M. Kondo for the chemical analyses. N. Hijii and H. Kajimura, and the members of the Laboratory of Forest Protection, Nagoya University, made valuable suggestions about this study. This study was supported in part by Ministry of the Environment of Japan, Nippon Life Insurance Foundation, and Grants-inAid for Scientific Research (No. 14005348, 13356003 and 14206019) from the Ministry of Education, Culture, Sports, Science and Technology, Japan.

\section{References}

Akashi, N. and Nakashizuka, T. 1999. Effect of bark-stripping by Sika deer (Cervus nippon) on population dynamics of a mixed forest in Japan. Forest Ecology and Management 113: 75-82.

Anderson, R. C. and Loucks, O. L. 1979. White-tailed deer (Odocoileus virginianus) influence on structure and composition of Tsuga canadensis forests. Journal of Applied Ecology 16: 855-861.

Ando, M., Yokota, H. and Shibata, E. 2003. Bark stripping preference of sika deer, Cervus nippon, in terms of bark chemical contents. Forest Ecology and Management 177: 323-331.

Faber, W. E. 1996. Bark stripping by moose on young Pinus sylvestris in south-central Sweden. Scandinavian Journal of Forest Research 11: $300-306$

Fuller, R. J. and Gill, R. M. A. 2001. Ecological impacts of increasing numbers of deer in British woodland. Forestry 74: 193-199.

Gill, R. M. A. 1992. A review of damage by mammals in north temperate forests: 1. Deer. Forestry 65: 145-169.

Hoshino, S. 1985. Embarrassment of Rumen. In (M. Kandatsu and K. Sudo, eds.) Rumen No Sekai [The World of Rumen]. Pp. 604 646. Nousangyoson Cultural Association, Tokyo (in Japanese).

Ikeda, K. 2002. The food habits of sika deer in a coniferous plantation area, northern Kyushu. Journal of Japanese Forestry Society 84 175-179 (in Japanese with English Abstract).

Itabashi, H. 1998. Digestion in Rumen. In (Y. Sasaki and Y. Obara, eds.) Hansudoubutsu No Eiyouseirigaku [Nutritional Physiology of Ruminant]. Pp. 87-112. Nousangyoson Cultural Association, Tokyo (in Japanese).

Ivlev, V. S. 1965. Gyorui No Eiyouseirigaku [Experimental ecology of the feeding of fishes]. (Y. Kodama, T. Yoshiwara, Trans.) Tatarasyobo, Yonago, 261 pp. (in Japanese).

Jayasekara, P. and Takatsuki, S. 2000. Seasonal food habits of a sika deer population in the warm temperate forest of the westernmost part of Honshu, Japan. Ecological Research 15: 153-157.

Kaji, K., Ohtaishi, N. and Koizumi, T. 1984. Population growth and its effect upon the forest used by Sika deer on Nakanoshima Island in Lake Toya, Hokkaido. Acta Zoologica Fennica 172: 203-205.

Kanzaki, N., Maruyama, N., Koganezawa, M. and Taniguchi, M. 1998. Bark stripping by sika deer in Nikko, Tochigi Prefecture. Wildlife Conservation 3: 107-117 (in Japanese with English abstract)

Kemp, A. and t'Hart, M. L. 1957. Grass tetany in grazing milking cows. Netherlands Journal of Agricultural Science 5: 4-17.

Khan, J. A., Rodgers, W. A., Johnsingh, A. J. T. and Mathur, P. K. 1994. Tree and shrub mortality and debarking by sambar Cervus unicolor (Kerr) in Gir after a drought in Gujarat, India. Biological Conservation 68: 149-154.

Maeji, I., Yokoyama, S. and Shibata, E. 1999. Population density and range use of sika deer, Cervus nippon, on Mt. Ohdaigahara, 
central Japan. Journal of Forest Research 4: 235-239.

McIntyre, E. B. 1972. Barkstripping - a natural phenomenon. Scottish Forestry 26: 43-50.

Miquelle, D. G. and Van Ballenberghe, V. 1989. Impact of bark stripping by moose on aspen-spruce communities. Journal of Wildlife Management 53: 577-586.

Motta, R. 1996. Impact of wild ungulates on forest regeneration and tree composition of mountain forests in the Western Italian Alps. Forest Ecology and Management 88: 93-98.

Nagaike, T. and Hayashi, A. 2003. Bark-stripping by sika deer (Cervus nippon) in Larix kaempferi plantations in central Japan. Forest Ecology and Management 175: 563-572.

Oi, T. and Itoya, Y. 1997. Nutritional evaluation of Cryptomeria japonica damaged by sika deer (Cervus nippon). Proc. IUFRO workshop. Pp. 284-291. Forestry Research Institute, Seoul.

Okumura, J. and Tanaka, K. 1995. Doubutu Eiyougaku [Animal Nutrition]. Asakura Publishing Co., Tokyo. 226 pp. (in Japanese).

Parks, C. G., Bednar, L. and Tiedemann, A. R. 1998. Browsing ungulates - An important consideration in dieback and mortality of Pacific yew (Taxus brevifolia) in a northeastern Oregon stand. Northwest Science 72: 190-197.

Randveer, T. and Heikkila, R. 1996. Damage caused by moose (Alces alces L.) by bark stripping of Picea abies. Scandinavian Journal of Forest Research 11: 153-158.

Robbins, C. T. 1993. Wildlife feeding and nutrition, 2nd ed. Academic Press, San Diego. 352 pp.

Sakabe, T., Yabe, T., Yajima, T., Shibuya, M. and Takahashi, K. 1998. Tree damage by sika deer in a wintering area in the Iwaobetsu district on the Shiretoko Peninsula. Hokkaido Daigaku Nougakubu Ensyurin Kenkyu Houkoku [Research Bulletin of Hokkaido University Forests] 55: 113-122 (in Japanese with English abstract).

Sekine, T. and Sato, H. 1992. Tree barking by sika deer, Cervus nippon Temminck, on Mt. Ohdaigahara. Japanese Journal of Ecology 42: 241-248 (in Japanese with English abstract).
Stafford, K. J. 1997. The diet and trace element status of sambar deer (Cervus unicolor) in Manawatu district, New Zealand. New Zealand Journal of Zoology 24: 267-271.

Takatsuki, S. and Gorai, T. 1994. Effects of Sika deer on the regeneration of a Fagus crenata forest on Kinkazan Island, northern Japan. Ecological Research 9: 115-120.

Ueckermann, E. 1983. The effect of various feed components on the effect of bark-stripping by red deer. Zeitschrift Jagdwissenschaft 29: 31-47 (in German with English summary).

Ueda, H., Takatsuki, S. and Takahashi, Y. 2002. Bark stripping of hinoki cypress by sika deer in relation to snow cover and food availability on Mt. Takahara, central Japan. Ecological Research 17: 545-551.

Van Soest, P. J. and Wine, R. H. 1967. Use of detergents in the analysis of fibrous feeds. IV. Determination of plant cell-wall constituents. Journal of the Association of Official Analytical Chemists 50: $50-55$.

Virtanen, R., Edwards, G. R. and Crawley, M. J. 2002. Red deer management and vegetation on the Isle of Rum. Journal of Applied Ecology 39: 572-583.

Welch, D., Staines, B. W. Scott, D. and Catt, D. C. 1987. Bark stripping damage by red deer in a Sitka spruce forest in Western Scotland. I. Incidence Forestry 60: 249-262.

Yokoyama, S. and Shibata, E. 1998. Characteristics of Sasa nipponica grassland as a summer forage resource for sika deer on Mt. Ohdaigahara, central Japan. Ecological Research 13: 193-198.

Yokoyama, S., Koizumi, T. and Shibata, E. 1996. Food habits of sika deer as assessed by fecal analysis in Mt. Ohdaigahara, central Japan. Journal of Forest Research 1: 161-164.

Yokoyama, S., Maeji, I., Ueda, T., Ando, M. and Shibata, E. 2001. Impact of bark stripping by sika deer, Cervus nippon, on subalpine coniferous forests in central Japan. Forest Ecology and Management 140: 93-99.

Received 5 December 2003. Accepted 13 May 2004. 